\title{
HYDROTROPE-IN DUCED MICELLAR PHASE OF SODIUM DODECYL SULFATE AS NEW DETERGENT FOR EXTRACTION AND STABILIZATION OF PROTEINS
}

\author{
Viktoriia Starova $^{1, *}$, Sergey Kulichenko ${ }^{1}$
}

https://doi.org/10.23939/chcht12.02.196

\begin{abstract}
X-ray phase analysis and IR spectroscopy data have confirmed a gel-like nature of sodium dodecyl sulfate micellar phase induced by sodium chloride and salicylic acid additives. This phase essentially consists of water $\left(\omega_{\mathrm{H} 2 \mathrm{O}}>50 \%\right)$, which is connected with main components of the micellar-extraction system through intermolecular hydrogen bonds. Capacity of such micellar phase to quantitatively extract of proteins $(R>94 \%)$ with saving of their catalytic activities and dispersity was found.
\end{abstract}

Keywords: micellar extraction, sodium dodecyl sulfate, protein, native state, catalytic activity.

\section{Introduction}

Determination of structure and properties of protein macromolecules is quite difficult issue and requires creating of new effective techniques of their extraction and purification $[1,2]$. Thus, the most of membrane proteins have been little studied and only in one functional state. Such proteins are characterized by high affinity for a lipid membrane and low solubility in water owing to presence of hydrophobic domains in their structure. At that the proteins solubilization by existing surface-activeagents is often accompanied by loss of their native state. Therefore, designing of new suitable detergents with high ability to self-aggregation, protein solubitization and its functional stabilization is still a topical issue [3, 4].

Nowadays, micelle extraction is a widely-used approach of environmentally benign extraction of protein substrates, that easily combines with various detection and separation techniques $[5,6]$. It may be caused by high capacity of micelle-forming detergents to efficient cell lysis and quantitative extraction of macromolecules that have both hydrophobic and hydrophilic domains [3].

\footnotetext{
${ }^{1}$ Taras Shevchenko National University of Kyiv,

64 Volodymyrska St., 01033 Kyiv, Ukraine

*starova-v@ukr.net

(c) Starova V., Kulichenko S., 2018
}

Phase separation of the micellar solutions that occurred due to some temperatures changes and addition of hydrotropes or electrolytes improves proteins solubilization [5]. Generally, water-soluble proteins stay in solution but hydrophobic substrates precipitate with micellar phase $[3,4]$.

It is known that anionic surfactant sodium dodecyl sulfate (SDS) is one of commonly used detergents for extraction of membrane proteins. Unfortunately, the application of SDS solution can lead to denaturation of protein and loss of its activity [3, 4]. In addition, the volumetric crystalline SDS phases which formed at the temperature below the Kraft point $\left(T_{K}\right)$ and at the presence of electrolytes are characterized by low degree of proteins extraction [5, 7]. Nevertheless, previously we established that compact liquid micellar phase can be formed from mixtures of SDS and modifying additives of sodium chloride and salicylic acid (HSal) at the temperatures of approximately 298-303 K. Unlike the majority of extraction systems this phase is able to effectively extract the proteins of different nature not only at isoelectric point (pI) but also in the conditions of proteins cationic forms domination $\mathrm{pH} \leq \mathrm{pI}$ [6-8]. In our opinion, the SDS-NaClHSal micellar-extraction system is able to promote the stabilization of native state of protein molecules. This study focuses on aggregate state and composition of such hydrotrope-induced micellar phase and its influences on catalytic activities and colloidal stability of proteins.

\section{Experimental}

Hydrotrope-induced micellar phase of SDS was prepared by the technique [7]. The working solutions of SDS and $\mathrm{NaCl}$ were prepared by dissolution of their exactly weighted portions in distilled water, while the solution of salicylic acid was prepared by dissolution of its exact mass in $0.05 \mathrm{M}$ SDS solution. SDS was produced by Merck (content of the title substance >98.5\%). Modifying additives of $\mathrm{NaCl}$ and salicylic acid were of analytical grade. The required $\mathrm{pH}$ values were provided by the 
addition of $0.1 \mathrm{M} \mathrm{HCl}$ and $\mathrm{NaOH}$ solutions (volumetric standards). The acidity of the solutions was controlled by a $\mathrm{pH}$ meter (pH-340) with a glass electrode ESL-43-07 (Belarus).

After the aqueous and micellar phases segregated completely, the aqueous phase was separated by decantation. The resulting micellar phase of certain volume $\left(V_{m p h}\right)$ was diluted to $10.0 \mathrm{ml}$. Then, the content of main components of micellar phase was determined in the solution. Amount of SDS in the micellar phase was evaluated according to [9] by two-phase titration with using of cationic surfactant solution (cetylpyridinium chloride) as titrant and methyl green as indicator. Volhard method was used for argentometric determination of sodium chloride concentration [10]. The content of salicylic acid was determined spectrophotometrically by own absorption in the UV spectrum. The absorption spectra were measured on a 2800 UVIVIS spectrophotometer (UNICO, USA).

Investigation of the aggregate state of micellar phase was carried out by X-ray phase analysis using X-ray diffractometer DRON 4-07 (Burevestnik, St. Petersburg) with $\mathrm{CuK} \alpha$-radiation and Ni filter $(\lambda=0.154 \mathrm{~nm})$. XRD patterns were obtained at X-ray tube voltage of $30 \mathrm{kV}$, amperage of $20 \mathrm{~mA}$ and step of $0.04^{\circ}$, the exposure time of each point was $3 \mathrm{~s}$.

IR spectra of micellar phases before and after thermal drying were recorded with using of IRspectrometer NEXUS-470 (Nicolet, USA) in the range of $4000-400 \mathrm{~cm}^{-1}$ and resolution of $4 \mathrm{~cm}^{-1}$ in the mode of Attenuated Total Reflection (prefix Smart Orbit, optical element - diamond).

The degree of proteins extraction $(R)$ was evaluated with biuret test [7] by the measurement of absorbance of aqueous-micellar solutions before and after phase separation as well as the absorbance of the surfactant-rich phase after its dilution. The working solutions of ovalbumin were prepared by the dissolution of $1 \mathrm{~g}$ egg white in $100 \mathrm{ml}$ of distilled water according to procedure [11]. Ovalbumin concentration was calculated in $\mathrm{mg} / \mathrm{ml}$ (based on dry substance). The solutions of casein, hemoglobin $(\mathrm{Hb})$, bovine serum albumin, and gelatin were prepared by dissolving the corresponding weighted portions in $0.05 \mathrm{M}$ SDS solution. Preliminary we estimated the accuracy of the $\mathrm{R}$ value measurements in the investigated systems which averaged $\pm 0.2 \%$.

Disperse state changing of ovalbumin after its extraction into SDS micellar phase was evaluated spectrophotometrically by light scattering solutions in the long-wavelength region $(500-800 \mathrm{~nm})$. The turbidity value was calculated according to the formula (1):

$$
\tau^{560}=2.3 \cdot \mathrm{A}^{560} / l
$$

where $\mathrm{A}^{560}$ - optical density of the solution at $560 \mathrm{~nm}, l-$ thickness of the cuvette $2 \mathrm{~cm}$. Scattering factor $(F)$ values were estimated as the slope angles of the dependencies $\lg A-\lg \lambda[12]$.

It is known that the proteins lose their catalytic activity due to denaturation. Thus, the peroxidaze activity is inherent property of hemoproteins in native state. Therefore, to confirm the saving of proteins in their native state after micellar extraction, the catalytic properties of hemoglobin in SDS micellar phase were verified. Establishing of catalytic activity of hemoglobin, as a model substrate, in water and SDS micellar phase was carried out according to [13]. Oxidation of bromopyrogallol red (BPR) by hydrogen peroxide was used as indicator reaction. The rate of the reaction $(V)$ was monitored spectrophotometrically by registering of optical density changes (at the wavelength of maximum absorbance $540 \mathrm{~nm}$ ) over time. Dependencies $A^{540}=f(t, \mathrm{~min})$ were obtained for micellar solutions with different concentration of peroxide $\left(C_{\mathrm{H} 2 \mathrm{O} 2}=0.2-1 \cdot 0 \cdot 10^{-5} \mathrm{M}\right)$. Then, the typical saturation curve for one substrate reaction obeying Michaelis-Menten kinetics was obtained; Keynes' function was its linear approximation. The ratio of Michaelis-Menten constant $\left(K_{M}\right)$ to maximum speed of reaction $\left(V_{\max }\right)$ was calculated in accordance with: $K_{M} / V_{\max }=19.2+9.94 \cdot C_{\mathrm{H} 202} \cdot 10^{-6} \mathrm{M}\left(r^{2}=0.996\right)-$ for micellar phase at the presence of $\mathrm{Hb} ; K_{M} / V_{\max }=$ $=133.89+4.14 \cdot C_{\mathrm{H} 202} \cdot 10^{-6}\left(r^{2}=0.985\right)-$ micellar phase without $\mathrm{Hb}$ additive; $K_{M} / V_{\max }=34.8+24.7 \cdot C_{\mathrm{H} 2 \mathrm{O} 2} \cdot 10^{-6} \mathrm{M}$ $\left(r^{2}=0.998\right)-$ for aqueous solution. $1 / V_{\max }$ was determined as the slope of such dependencies. The $\mathrm{Hb}$ catalytic activity $\left(A, \mathrm{~mol}^{-1} \cdot \mathrm{min}^{-1}\right)$ was calculated by the formula (2):

$$
A=\Delta A^{540} / t \cdot C_{\mathrm{Hb}}
$$

where $t$ is incubation period of $20 \mathrm{~min}$.

\section{Results and Discussion}

\subsection{Composition of Hydrotrope-Induced Micellar Phase of SDS}

Hydrotrope-induced SDS phase is a colorless viscous fluid which is formed over a narrow range of concentrations of the components of micellar-extraction system: $\quad C_{\mathrm{SDS}}=0.04-0.10 \mathrm{M} ; \quad C_{\mathrm{NaCl}}=0.7-1.4 \mathrm{M}$; $C_{\text {HSal }}=0.02-0.04 \mathrm{M}$ (Fig. 1). This liquid phase exists until the molecular form of hydrotrope dominates $\left(\mathrm{pH}<\mathrm{pK}_{\mathrm{HSal}}^{\mathrm{f}}<4\right)[5,7]$.

Table 1 shows the changes of composition of SDS phase in response to variations of components concentration in start micellar solution. The content of system components in SDS phase increases at rising of their initial concentration. Increasing of sodium chloride 
concentration promotes the formation of solid precipitate; on the contrary, increasing of the salicylic acid concentration stimulates the formation of liquid micellar phase. It is interesting, that water is a predominant component of liquid SDS phase.

SDS phase which formed at $C_{\mathrm{SDS}}=0.10 \mathrm{M}$, $\mathrm{C}_{\mathrm{HSal}}=0.04 \mathrm{M}, C_{\mathrm{NaCl}}=1.0 \mathrm{M}\left(\mathrm{pH}=2, T_{K}=301 \mathrm{~K}\right)$ was chosen for further investigations owing to its ability to ensure the achievement of high coefficients of absolute preconcentration $K=20$ at $V_{0}=10 \mathrm{ml} ; K=50$ at $V_{0}=50 \mathrm{ml}$.

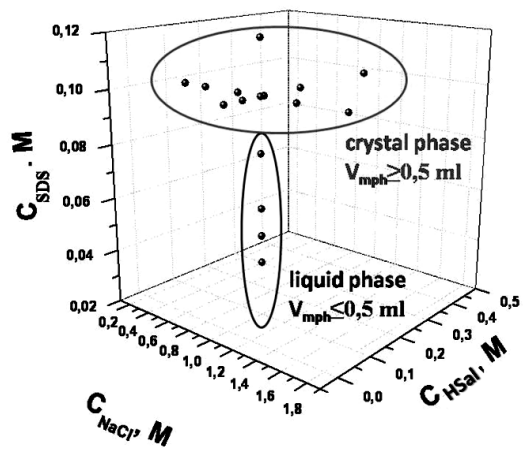

Fig. 1. Optimal conditions for obtaining of liquid SDS micellar phase induced by sodium chloride and salicylic acid

\subsection{Aggregate State of SDS M icelle Phase}

XRD phase analysis reveals the amorphous nature of the SDS micelle phase, Fig. 2a. X-ray amorphous patterns show the existence of reproducible short-range molecular order and no long-range molecular order that is typical for glassy materials [14]. It was found that SDS liquid micellar phase turns in polymorphous powder after removing of physically bounded water by drying at $343 \mathrm{~K}$ with circulating air, Fig. 2b. Generally, micellar phase after drying is similar to the initial mixture of the components - crystals of salicylic acid (monoclinic structure with space group P21/c), sodium chloride (cubic structure with space group Fm3m) and amorphous SDS (supporting data). Interestingly, dried SDS phase $\left(V_{m p h} \approx 1.0 \mathrm{ml}\right)$ turns to a highly viscous liquid after adding of $1.0 \mathrm{ml}$ of distilled water and keeping during one day. Obtained XRD pattern for such liquid differs from the pattern of original micellar liquid phase (Fig. 2b). The irreversible destruction of the primary structure of the liquid SDS phase is notable and directly confirms a gellike nature of this phase.

Specific halos observed in the continuous X-ray diffraction for SDS phase after its Gaussian expansion $\left(2 \theta \approx 21^{\circ}, 38^{\circ}\right.$ and $57^{\circ}$ ) allow us to suggest the presence of structured water in phase composition (Fig. 2a, curves 1-3). Thus, the diffraction patterns shown in Fig. 2a are well correlated with XRD patterns for liquid water in interpretation of the random close packing of materials (when exponent describing random packing came out to be $N \sim 5$ ) [14]. Small peak at $\approx 28^{\circ} 2 \theta$ is observed due to the presence of amorphous SDS (Fig. 2a, curve 4).

IR spectra of liquid and dried micellar SDS phases were also studied, Fig. 3. Dried phase is characterized by typical peaks for salicylic acid arising from stretch vibrations of hydroxy-substituted phenyl group $\left(v_{\mathrm{OH}}=3471 \mathrm{~cm}^{-1}\right)$ and carboxyl group $\left(v_{\mathrm{OH}}=3471 \mathrm{~cm}^{-1}\right.$; $\left.v_{\mathrm{C}(\mathrm{O}) \mathrm{H}}=2269 \mathrm{~cm}^{-1} ; v^{\mathrm{as}}{ }_{\mathrm{C}=\mathrm{O}}=1663 \mathrm{~cm}^{-1}\right)$ which have formed the intramolecular hydrogen-bonds between each other. On the spectrum of liquid micellar phase the intensities of these bands rises and wide intense band of $v_{\mathrm{OH}}$ vibrations appears at $3373 \mathrm{~cm}^{-1}$. The lowering of IR absorption frequencies occurred owing to formation of intermolecular hydrogen bonds between water and salicylic acid in liquid SDS phase, which promote decreasing of force constant of the chemical bonds of functional groups. Stretching and deformation vibrations of aromatic bonds of salicylic acid $\left(v_{\mathrm{C}=\mathrm{C}}^{\mathrm{s}}=1606 \mathrm{~cm}^{-1} ; v_{\mathrm{C}-\mathrm{C}}=1462 \mathrm{~cm}^{-1} ; \delta_{\mathrm{C}-\mathrm{H}}=969 \mathrm{~cm}^{-1}\right)$, and also aliphatic bonds of SDS and its sulfogroups $\left(v_{\mathrm{CH} 2}^{\mathrm{s}}=2850 \mathrm{~cm}^{-1} ; v^{\mathrm{as}}{ }_{\mathrm{CH} 2}=2918 \mathrm{~cm}^{-1} ; \delta_{\mathrm{CH} 3}=1382 \mathrm{~cm}^{-1}\right.$; $\left.v^{\mathrm{as}}{ }_{\mathrm{SO} 3}=1204 \mathrm{~cm}^{-1} ; v_{\mathrm{SO} 3}^{\mathrm{s}}=1060 \mathrm{~cm}^{-1}\right)$ are also observed on the spectrum of the dried phase. Intensity of IR absorption bands of liquid phase in the range of $2800-2950 \mathrm{~cm}^{-1}$ is lower in comparing with the spectrum of the dried SDS phase; on the contrary, the IR absorption intensity is higher in the spectral region of $1600-1670 \mathrm{~cm}^{-1}$. Described features of the IR spectrum of liquid SDS phase confirm the existence of chemically connected water in its content. This may also indicate a gel-like nature of investigated hydrotrope-induced phase of SDS.

Table 1

Phase composition in dependence on concentrations of SDS and modifying additives in start solution

\begin{tabular}{|c|c|c|c|c|c|c|c|}
\hline \multicolumn{3}{|c|}{ Components concentrations, $\mathrm{M}$} & \multirow{2}{*}{$V_{m p h}, \mathrm{ml}$} & \multicolumn{4}{|c|}{ Mass fraction, $\%$} \\
\hline$C_{\mathrm{SDS}}$ & $C_{\mathrm{HSal}}$ & $C_{\mathrm{NaCl}}$ & & $\omega_{\mathrm{SDS}}$ & $\omega_{\mathrm{HSal}}$ & $\omega_{\mathrm{NaCl}}$ & $\omega_{\mathrm{H} 2 \mathrm{O}}$ \\
\hline $\mathbf{0 . 1 0}$ & 0.04 & 1.0 & 0.5 & 42 & 3.0 & 3.0 & 52 \\
\hline 0.07 & 0.04 & 1.0 & 0.8 & 38 & 5.5 & 3.5 & 53 \\
\hline 0.05 & 0.04 & 1.0 & 1.2 & 13 & 3.4 & 2.6 & 81 \\
\hline 0.10 & 0.02 & 1.0 & 2.6 & 8.3 & 0.3 & 1.4 & 90 \\
\hline 0.10 & 0.04 & 0.7 & 0.7 & 43 & 2.3 & 2.9 & 51 \\
\hline 0.10 & 0.04 & 1.3 & 1.0 & 40 & 2.0 & 8.0 & 50 \\
\hline
\end{tabular}

Notes: $V_{0}=10 \mathrm{ml}, \mathrm{pH}=2$ 


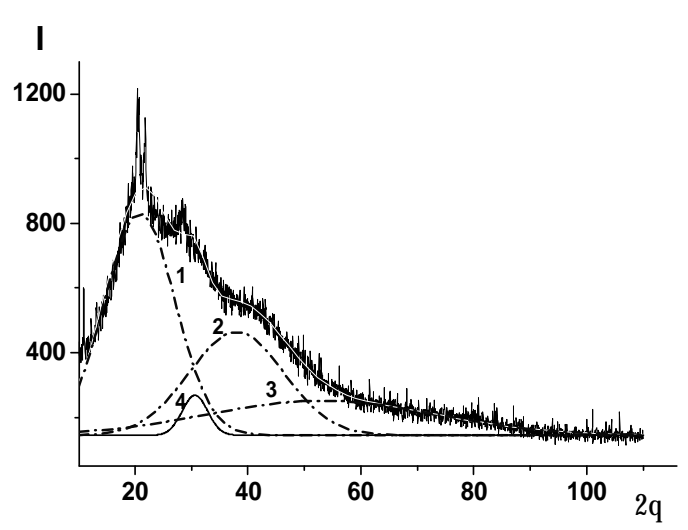

a)

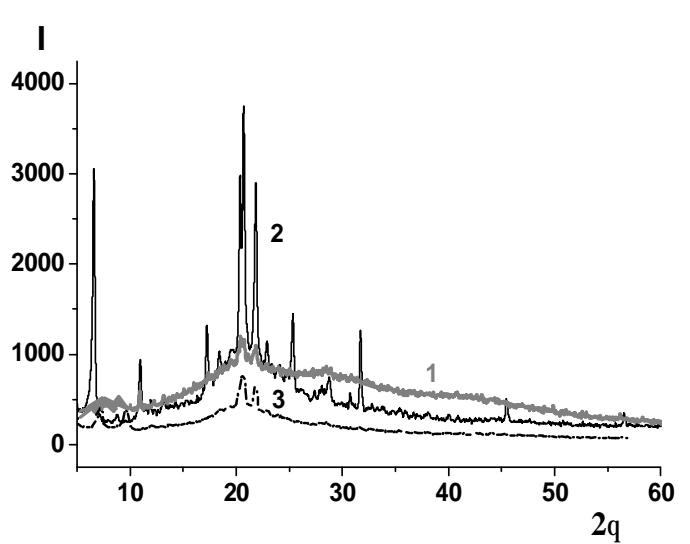

b)

Fig. 2. X-ray diffractograms of micellar phase obtained in SDS-NaCl-HSal system. SDS phase in liquid state (a, 1b), after its drying (2b) and reverse wetting (3b)

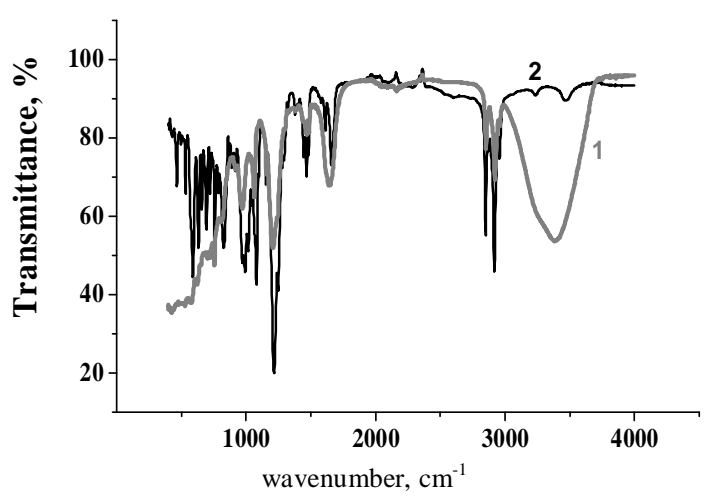

Fig. 3. IR spectra of investigated SDS micellar phase before (1) and after drying (2)

\subsection{Influence of Main Components of M icellar Extraction System on Proteins Dispersity}

Noteworthy, the proteins of different nature are almost completely extracted by hydrotrope-induced micellar phase of SDS, Table 2.

Turbidimetric data support the view that micelles of SDS can stabilize the dispersion degree of proteins. Table 3 shows that the $F$ values of pure SDS micellar solution and SDS-ovalbumin mixture $\left(C_{\mathrm{SDS}}>\mathrm{CCM}\right)$ are the same and approximately are equal to four, which confirms their pseudomolecular degree of dispersion. This proves the capacity of SDS micelles to solubilize of ovalbumin molecules without causing denaturation. In contrast, low concentrations of surfactant exhibit a salting-out effect and in solution with $C_{\mathrm{SDS}}<\mathrm{CCM}$ ovalbumin forms large colloidal particles $(F<<4)$. Sodium chloride and salicylic acid also have a salting-out action on ovalbumin.

Table 2

Extraction degree of proteins by liquid micellar phase of SDS-NaCI-HSal

\begin{tabular}{|l|c|c|}
\hline \multicolumn{1}{|c|}{ Protein } & $\mathrm{Mr}, \mathrm{Da}$ & $\mathrm{R}, \%$ \\
\hline Ovalbumin & $4.3 \cdot 10^{4}$ & 98 \\
\hline Hemoglobin & $6.4 \cdot 10^{4}$ & 95 \\
\hline Bovine serum albumin & $6.7 \cdot 10^{4}$ & 96 \\
\hline Casein & $(7.5-10) \cdot 10^{4}$ & $>99$ \\
\hline Gelatin & $30 \cdot 10^{4}$ & $>99$ \\
\hline
\end{tabular}

Notes: $C_{\text {protein }}=0.10 \mathrm{mg} / \mathrm{ml}, C_{\mathrm{SDS}}=0.10 \mathrm{M}, C_{\mathrm{NaCl}}=1.0 \mathrm{M}, \mathrm{C}_{\mathrm{HSaI}}=0.04 \mathrm{M}, \mathrm{pH}=2.5, V_{0}=10 \mathrm{ml}, K=20$ 
Dependence of scattering factor changes on composition of the system

\begin{tabular}{|l|c|c|}
\hline \multicolumn{1}{c|}{ Solution } & $\tau^{560}$ & $F$ \\
\hline SDS & 0.003 & 3.6 \\
\hline SDS-NaCl-HSal & $\mathbf{0 . 0 1 7}$ & $\mathbf{2 . 9}$ \\
\hline Protein & 0.006 & $>4$ \\
\hline Protein-SDS & 0.010 & 3.9 \\
\hline Protein-SDS & 0.015 & 1.6 \\
\hline Protein-NaCl & 0.009 & 2.2 \\
\hline Protein-HSal & 0.024 & 1.8 \\
\hline Protein-SDS-NaCl & 0.024 & 2 \\
\hline Protein-SDS-HSal & 0.008 & 2.7 \\
\hline Protein-SDS-NaCl-HSal & $\mathbf{0 . 0 2 3}$ & $\mathbf{2 . 8}$ \\
\hline
\end{tabular}
$V_{0}=10 \mathrm{ml}$

Notes: $C_{\text {ovalbumin }}=0.10 \mathrm{mg} / \mathrm{ml}, C_{\mathrm{SDS}}>\mathrm{CCM}=0.10 \mathrm{M},{ }^{*} C_{\mathrm{SDS}}<\mathrm{CCM}=5 \cdot 10^{-3} \mathrm{M}, C_{\mathrm{NaCl}}=1,0 \mathrm{M}, C_{\mathrm{HSaI}}=0.04 \mathrm{M}, \mathrm{pH}=2.5$,

Table 4

Kinetic parameters of reaction of BPR oxidation by hydrogen peroxide at the presence of $\mathrm{Hb}$ in water (I), in SDS micellar phase (II) and in SDS micellar phase without Hb (III)

\begin{tabular}{|l|c|c|c|}
\hline \multicolumn{1}{|c|}{ Parameter } & I & II & III \\
\hline$V_{\max }, \mathrm{min}^{1}$ & 0.041 & 0.101 & 0.241 \\
\hline$K_{M}, \mathrm{M}$ & $1.4 \cdot 10^{-6}$ & $1.9 \cdot 10^{-6}$ & $3.2 \cdot 10^{-5}$ \\
\hline$A, \mathrm{~mol}^{-1} \cdot \mathrm{min}^{-1}$ & $5.2 \cdot 10^{4}$ & $11 \cdot 10^{4}$ & $5.0 \cdot 10^{-3}$ \\
\hline
\end{tabular}

Notes: $C_{\mathrm{Hb}}=0.017 \mathrm{mg} / \mathrm{ml}, C_{\mathrm{BPR}}=3.6 \cdot 10^{-6} \mathrm{M}, C_{\mathrm{SDS}}=0.10 \mathrm{M}, C_{\mathrm{HSaI}}=0.04 \mathrm{M}, C_{\mathrm{NaCl}}=1.0 \mathrm{M}, \mathrm{pH}=6.2$

\section{Supporting data}

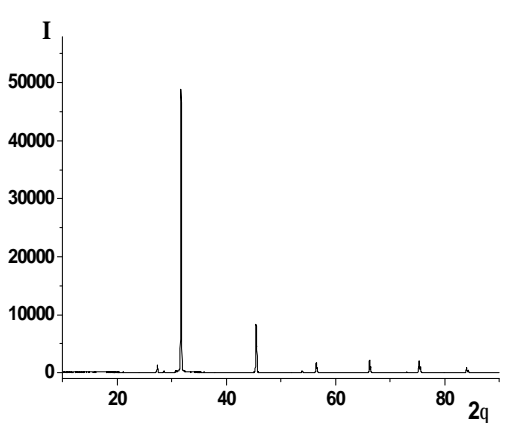

a)

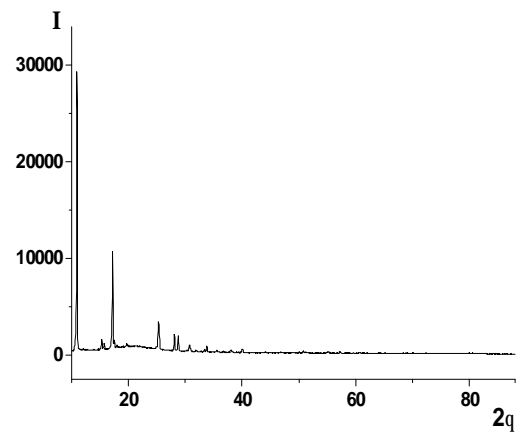

b)

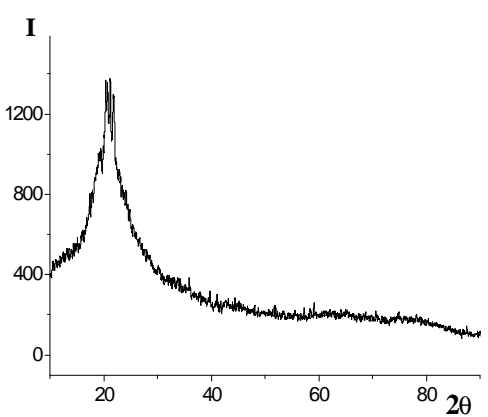

c)

X-ray diffractograms of polycrystalline samples of sodium chloride (a), salicylic acid (b) and amorphous powder of sodium dodecyl sulfate (c)

Obtained values of $F$ for micellar extraction system in the presence and absence of protein are almost equivalent. The $F$ value of ovalbumin-SDS-NaCl-HSal solution remains unchanged as the temperature rises from 296 to $313 \mathrm{~K}$. On the other hand, the $F$ value reduces from 3.9 to 0.5 as temperature decreases from 296 to $291 \mathrm{~K}$, respectively. The particle size in this mixture gradually increases owing to beginning of micellar phase formation at $T_{K} \leq 296 \mathrm{~K}$. These effects can indicate the preservation of native state of proteins after their extraction into such hydrotrope-induced micellar phase.

\subsection{Catalytic Activity of Hemoglobin into SDS Micellar Phase}

Table 4 shows the two-fold increase in catalytic activity of hemoglobin after its extraction in hydrotropeinduced SDS phase, which confirms the stabilization of 
the native protein nature in such organized system. Noteworthy, the rate of BPR oxidation by peroxide in SDS phase without $\mathrm{Hb}$ decreases.

The obtained results well correlate with literature data that demonstrate the ability of anionic surface-active substances to improve the catalytic activity of enzymes [15].

\section{Conclusions}

Observed stabilization of disperse state of ovalbumin into such SDS micellar phase confirms the absence of a salting out action of micellar-extraction system SDS-NaCl-HSal on proteins. At that two-fold increase in catalytic activity of hemoglobin after its solubilization by SDS micelles testifies to the stabilization of native protein nature in such organized system. The ability of hydrotrope-induced SDS micellar phase to completely extract various proteins in native state implies a potential for its application for investigation of biological objects containing a trace amount of protein with hydrophylic and hydrophopic domains.

\section{References:}

[1] Sova V., Kusaikin M.: Methodicheskoe Rukovodstvo dlia Practicheskykh Zaniatiy. Izd-vo Dalnevost. Univ., Vladivostok 2006.

[2] Allard J., Baird A., Davidson G., et al.: Sci. Justice, 2007, 47, 160. https://doi.org/10.1016/j.scijus.2007.09.010

[3] Johnson M., Yakimchuk K.: Mater. Methods, 2013, 3, 163. https://doi.org/10.13070/mm.ru.3.163

[4] Matar-Merheb R., Rhimi M., Leydier A. et al.: Plos One, 2011, 6. https://doi.org/10.1371/journal.pone.0018036

[5] Kulichenko S., Starova V.: Chem. Pap., 2010, 64, 98. https://doi.org/10.2478/s11696-009-0086-7

[6] González de la Vara L., Alfaro B.: Anal. Biochem., 2009, 387, 280. https://doi.org/10.1016/j.ab.2009.01.035
[7] Starova V., Kulichenko S.: J. Anal. Chem., 2010, 65, 1244. https://doi.org/10.1134/S1061934810120038

[8] Knorre D., Myzina S.: Biochemistry: A Manual for Universities. Nova Science Books and Jrnls, New York 1998.

[9] Kulichenko S.: Visnyk Kyiv. Nats. Univ., 1997, 34, 55.

[10] Zhaporozhets O., Nadzhafova O., Smyk N. et al.: Rukovodstvo dlia Laboratornykh Rabot po Analiticheskoi Khimii. Izd-vo Kyiv. Univ., Kyiv 2005.

[11] Severin S., Soloveva G. (Ed.): Seminar po Biokhimii.

Uchebnoe Posobie. Izd-vo Moskov. Gos. Univ., Moskva 1989.

[12] Klenin V., Shepolev S., Lavrushin V.: Characteristicheskie

Funktsii Rasseivania Sveta Dispersnykh System. Izd-vo Saratov. Univ., Saratov 1977.

[13] Nadzhafova O., Drozdova M., Bosak V.: Visnyk Kyiv. Nats. Univ., 2006, 43, 23.

[14] Simon Bates. Advanced Analysis of Non-Crystalline (X-ray Amorphous) Materials and Dispersions. www. Tricliniclabs.com. [15] Davletshin A., Silvesrtova I., Zubov V. et al.: Vestnik Moscov. Univ., 1998, 39, 272.

Received: March 29, 2017 / Revised: June 06, 2017 / Accepted: August 28, 2017

\section{ГУДРОТРОП-ІНДУКОВАНА МІЦЕЛЯРНА ФАЗА ДОДЕЦИЛСУЛЬФАТУ НАТРІЮ ЯК НОВИЙ ДЕТЕРГЕНТ ДЛЯ ВИЛУЧЕННЯ ТА СТАБІЛІЗАЦЇ̈ БІЛКІВ}

\begin{abstract}
Анотація. Дані рентгенофазового аналізу та інфрачервоної спектроскопії підтверджують гелеподібну природу міцелярної фази додецилсульфату натрію індукованої добавками хлориду натрію та салічилової кислоти. Така міцелярна фаза переважно складається з води ( $\left.\omega_{\text {нго }}>50 \%\right)$, яка формує внутрішньомолекулярні водневі зв'язки з основними компонентами міцелярно-екстракиійної системи. Встановлена здатність даної міџелярної фази кількісно вилучати білки $(R>94 \%)$ із збереженням їх каталітичної активності та дисперсності.
\end{abstract}

Ключові слова: мічелярна екстракиія, додецилсульфат натрію, білок, нативний стан, каталітична активність. 